\title{
Social competence and academic achievement in immigrant adolescents in Portugal ${ }^{1}$
}

\author{
Sofia Guimarães \\ University of Roehampton
}

\author{
Ida Lemos and Cristina Nunes \\ Universidade do Algarve
}

\section{RESUMEN}

El objetivo del presente estudio fue el de evaluar la relación entre las competencias sociales, el desempeño académico y una serie de características familiares en una muestra de 98 adolescentes inmigrantes de la región del Algarve (Portugal). Se utilizó el Self-report Form del Social Skills Rating System y se recogieron datos sobre el desempeño escolar y las variables asociadas a la familia como la situación y cualificación laboral de los padres, el número de años en el país de acogida y la estructura familiar.

Los resultados mostraron algunas diferencias de grupo entre los adolescentes inmigrantes de primera y segunda generación en sus competencias sociales percibidas en términos de Auto-control y Cooperación, habiéndose hallado que el grupo de segunda generación reportaba niveles significativamente más bajos en ambas sub-escalas. Además, existía en ambos grupos de adolescentes una correlación positiva y significativa entre los resultados escolares y sus niveles reportados de Asertividad y Auto-control. Los resultados se discuten en relación a la intervención en las competencias sociales en contexto escolar.

Palabras-clave: adolescencia, inmigración, competencias sociales, rendimiento académico.

\section{ABSTRACT}

The aim of the present study was to examine the relation between social skills, academic achievement and a range of family characteristics in a sample of 98 school adolescent immigrants in the region of Algarve (Portugal). The Self-report Form of the Social Skills Rating System was used and data was gathered about the students' academic achievement and family related variables such as: parental employment and qualifications, number of years in the country and family structure.

The results show some interesting group differences between first- and second-generation adolescent immigrants in their perceived social skills in terms of Self-control and Cooperation, with the second generation group reporting significantly lower levels on these two subscales. Also, there was for all the adolescents a significant positive correlation between academic results and their reported levels of Assertion and Self-control. The results are discussed in relation to school-based social skills intervention.

Keywords: Adolescence, immigration, social skills, academic achievement.

\footnotetext{
1 Sofia Guimarães, University of Roehampton; Ida Lemos, Centro de Investigação sobre o Espaço e as Organizações, Universidade do Algarve; and Cristina Nunes, Centro de Investigação sobre o Espaço e as Organizações, Universidade do Algarve. Acknowledgements: This study was partially financed by Fundação a para Ciência e Tecnologia (FCT) of Portugal. Competing interests: The authors declare that they have no competing interests.

Correspondence: Cristina Nunes, Centro de Investigação sobre o Espaço e as Organizações, Universidade do Algarve. Campus de Gambelas, 8005-139 Faro, Portugal. csnunes@ualg.pt
} 
The percentage of immigrants living in Portugal has increased significantly during the last decade, rising from 207.000 immigrants from non UE European countries in the year 2000 to over 449,000 in 2010 (SEF, 2011). The Algarve, specifically, has the second highest percentage of immigrants in the country, only preceded by Lisbon (ACIME, 2005). The proportion of children of immigrants has been growing exponentially and if immigrants were not considered, the birth rate in the country would be in clear decline (SEF, 2011).

Similar increasing immigration rates have been observed across Europe (Strohmeir \& Schmitt-Rodermund, 2008), leading to a strong need for more studies about how these population groups are adapting to their host countries, in particular the youngest generation, who may present specific vulnerability factors in the process of social-cultural adjustment.

Adolescence is a period of enormous challenges and a very important time in terms of emotional development, attachment organization (Allen, Moore, Kupermic, \& Bell, 1998), differentiation and identity formation (Elmore, 2009). Immigrant adolescents like their nativeborn peers, face a set of challenges concerning social relationships, psychological well-being, academic achievement and identity formation, in addition to high challenges in terms of acculturation (Strohmeir \& Schmitt-Rodermund, 2008). Some of the difficulties faced during adolescence can therefore be exacerbated amongst immigrant groups.

The developmental path of immigrant adolescents occurs in a context of acculturation and depending on its characteristics this process may, or may not, promote a positive development of their identity, facilitate relationships with peers, and encourage a transition to a professional career or to higher education (Berry, 1980; Fry, 2007; Fuligni \& Hardway, 2004; Johnson, 2007). Social acculturation in immigrants may therefore increase some vulnerability factors (Sam, Vedder, Liebkind, Neto, \& Virta, 2008). These youngsters are, for example, at higher risk of facing discrimination (Huynh \& Fulligni, 2010), victimization (Ortega-Ruiz \& Rodrigues-Hidalgo, 2008) and of adopting health related risk behaviours (Brindis, Wolfe, Mccarter, Ball, \& Starbuck-Morales, 1995).

However, studies across different countries and focusing on different immigration groups are not always unanimous about the possible negative impact of immigration. In other words, adapting to a new culture and country may not lead to behaviour difficulties in adolescence. Some studies have in fact pointed to some positive outcomes amongst first-generation immigrant youths in terms of social-cultural adjustment (Sam et al., 2008). Differences in results highlight the complexity of variables associated with group and individual factors that moderate the process of adaptation and acculturation (Sam et al., 2008).

Nevertheless, immigration is a stressful process (Pavlopoulos, Obradavic, Dalla, Takis, Papathanassiou, \& Masten, 2008) associated, in the case of adolescents, with challenges regarding adaptation to the school context, the peer group, the cultural and social environment and often the new language. The school environment has been the focus of attention at 
this stage of development as it constitutes an important developmental context (Pavlopoulos et al., 2008), impacting on social identity and behaviour.

Some studies have focused particularly on school achievement among immigrant adolescents and differences have also appeared across studies. A recent large scale study of 13-yearold immigrant adolescents in Canada revealed that these groups presented significantly lower academic results than their non-immigrant counterparts (Queen's University, 2010). Many factors might explain this lower school performance, most likely related to immigrants' difficulties in adjusting and responding to the social and psychological challenges faced in the school environment. In the present study we explore some of the variables regarding adolescents' social skills and school success.

Social skills are fundamental in helping individuals to understand and adjust to different social contexts (Steedly, Schwartz, Levin, \& Luke, 2008). They are particularly important during challenging times of adjustment to a new setting. Wong, Lam, Yan and Hung (2004) found that immigrant students who were able to use social skills more effectively during stressful times of resettlement had better mental health outcomes. According to these authors social skills have a moderating effect on stress factors and are fundamental to this more vulnerable population.

Adolescents with good social skills are better adjusted than their peers with poor social skills, and are less likely to be at risk in terms of their social, emotional and academic outcomes (Brown \& Larson, 2009). It is also not surprising that social competence has, in general, been positively associated with adaptation to academic environments and school outcomes (Maleck \& Elliot, 2002). Social skills are also closely related to culture (Korem, Horenczyk, \& Tatar, 2011), making them of central concern when trying to better understand the social competences that facilitate the adjustment process of immigrant adolescents to the school context.

Academic performance is considered an important indicator of school success (Elmore, 2009). A better understanding of the variables associated with school outcomes in the immigrant population might contribute to our understanding of the role that social skills play in supporting adjustment to the academic context and offer directions for successful interventions. Schools can play an important role in providing the conditions that may facilitate social and emotional learning during this stage. Programmes developed to promote students' social skills including establishing and maintaining positive relationships, setting and achieving positive goals, and constructively handling interpersonal situations can have very positive outcomes both in terms of development as well as academic achievement (Durlak, Weissberg, Dymnicki, Taylor \& Schellinger, 2011). Social skills have also been associated with later achievement in life (Lleras, 2008), supporting individuals in the transition to adult roles (Elmore, 2009)

The present investigation is mostly an exploratory correlational study, which main aim is to understand the possible relationships between immigrant adolescents' school achieve- 
ment and adjustment and their perceptions about their social skills, and a range of family and immigration related variables.

\section{Methodology}

\section{Sample}

A total of 98 adolescents took part in the study, ranging in age from 12 to 18 years old, with 52 girls and 46 boys in the sample. For the purposes of the present study adolescents are defined according to American Psychological Association (2000, p.5) as youth ages 10 to 18 . A total of three public schools in the region of Algarve, Portugal participated in the study.

Table1 presents the number of students per level/year of education and number of students with special educational needs/ learning difficulties.

From the total sample studied, sixty-six adolescents were first-generation and thirty two were second-generation immigrants. Their country of origin was respectively, Africa $(n=$ 40), Brazil ( $n=28)$, Eastern European countries $(n=12)$ and other countries $(n=18)$, which reflects the present general immigration patterns in Portugal (see ACIME, 2005). The number of children living in the household ranged from a maximum of 5 to a minimum of 1 $(M=1.87 ; S D=0.86)$. Furthermore, $58.2 \%(n=57)$ of the participants attended regular teaching and $41.8 \%(n=41)$ were in work-oriented programmes. Only one of the participants (1\%) had special educational needs (SEN). Regarding the years of school failure, $41.8 \%$ of the participants $(n=41)$ had no reports of school failure, $27.6 \%(n=27)$ had failed one year, $18.4 \%$ $(n=18)$ had failed 2 years, and the remainder percentage of participants (12.2\%; $n=12$ ) had between 3 to 5 years of school failure.

\section{Instruments}

Data collection involved the completion of a socio-demographic questionnaire administered to the adolescents in the school context together with the Student Form from the Social Skills Rating System (Gresham \& Elliot, 1990).

The socio-demographic questionnaire covered a range of issues concerning: participants' age and gender, mother and father's age, parents' work status, labour qualification, and educational level. Adolescents' immigrant status, country of origin, parents' marital status, family structure, and number of children living at home was also included. Information regarding school and course attended by the students was also collected, including educational level, school retention, school absences and average grades.

In the present study academic competence was assessed through two different but re-

Table 1

Distribution of students per school year/level and number of students with special aducational needs/learning difficulties

\begin{tabular}{ll}
\hline School year & $\mathrm{N}$ \\
\hline Year 6 to 8 & 30 \\
Year 9 to 11 & 68 \\
Students with SEN/ learning Difficulties & 8 \\
\hline
\end{tabular}


Table 2

Number of years living in the country for the adolescents and their parents

\begin{tabular}{lcccc}
\hline & Mean & SD & Minimum & Maximum \\
\hline Adolescents & 6.4 & 3.4 & 1 & 14 \\
Fathers & 15 & 10.5 & 3 & 46 \\
Mothers & 13.4 & 10.4 & 1 & 40 \\
\hline
\end{tabular}

lated measures: average grades (calculated based on the grades of the main subjects) and retention rates. In Portugal school grades are on a 5 point-scale for years 6 to 9 and on a 20 point-scale from year 10 to 12 .

The Social Skills Rating System (SSRS) was originally developed by Gresham \& Elliot (1990) and provides a comprehensive picture of social behaviors, in reference to typicallydeveloping students. The Student Form of the SSRS is a self-report rating scale of social skills and includes the following subscales: Cooperation, Assertion, Self-control and Empathy.

\section{Procedure}

School boards were contacted and agreed to participate. Parental informed consent was acquired through a letter sent home through the children. Participation was voluntary and no compensation was offered. The data collection took place in the schools during lesson time.

The procedure to fill in the questionnaires was explained to the students by one of the researchers who remained in the classroom in order to answer any questions throughout the data collection.

\section{Results}

Several aspects of the results need to be highlighted here. Starting by looking at immigration status and years of living in the country, the data presented in table 2 , shows that, both students and their parents were very different in terms of the number of years living in Portugal, which reflects the fact that the sam-

Table 3

Parents' academic qualifications and present labour qualifications

\begin{tabular}{lcccc}
\hline \multicolumn{1}{c}{ Educational level } & Father & \multicolumn{2}{c}{ Mother } \\
\hline & $N$ & $\%$ & $N$ & $\%$ \\
\hline Primary level not completed & 8 & 8.2 & 7 & 7.1 \\
Primary school level completed & 45 & 45.9 & 44 & 44.9 \\
Completed studies at middle or secondary school & 20 & 20.4 & 31 & 31.6 \\
University degree & 3 & 3.1 & 4 & 4.1 \\
& & & & \\
\hline Labour qualification (present job) & & & & \\
\hline Untrained & 49 & 50 & 47 & 22.4 \\
Semi-skilled & 19 & 19.4 & 22 & 2 \\
Skilled & 3 & 3.1 & 2 & 2 \\
\hline
\end{tabular}


ple included both first- and second-generation immigrants and immigrants from different countries.

Regarding their parents' educational level almost half of the sample's parents had at least primary school education and untrained qualifications (table 3).

Table 4 presents the number of students in relation to their family structure and parents' marital situation. The data shows that over a quarter of adolescents lived with only one parent.

We also explored possible group differences regarding first- and second-generation in relation to social skills, academic related variables, including average results, school retention and school absence.
The results showed only group differences concerning their reported social skills in terms of Self-control and Cooperation, with the second generation group reporting lower average levels on these two subscales. For Self-control there was a mean difference of 1.46 , t-test 2.73 $(p<.01)$ and for Cooperation we found a mean difference of 1.82, t-test $2.6(p<.05)$.

No other significant group differences were noted for other variables. It was interesting to observe that no significant relation was found between family-related variables (family structure and parents marital status) and the students' academic performance and social skills.

No significant difference was observed between these two groups in relation to

Tabla 4

Number of students per type of family in relation to marital status and family structure

\begin{tabular}{lcc}
\hline Marital status & $N$ & $\%$ \\
\hline Married or living together & 52 & 53.1 \\
Divorced unattached & 21 & 21.4 \\
Divorced re-married & 18 & 18.4 \\
Unmarried & 2 & 2 \\
Widow/ widow re-married & 2 & 2 \\
\hline Family Structure & & \\
\hline Single-parent & 26 & 26.5 \\
Two-parent & 69 & 70.4 \\
other & 3 & 3.1 \\
\hline
\end{tabular}

Table 5

Correlation coefficients amongst school related variables

\begin{tabular}{lccc}
\hline & School Retention & Average Grades & School Absence \\
\hline School Retention & ---- & -.172 & $.202^{*}$ \\
Average Grades & & --- & .03 \\
School Attendance & & & --- \\
\hline$M(S D)$ & $1.1(1.2)$ & $2.91(.74)$ & $.98(1.3)$ \\
\hline
\end{tabular}

${ }^{*} p<.05,{ }^{* *} p<.01$ 
Table 6

Correlation coefficients amongst social skills and school related variables

\begin{tabular}{lcccc}
\hline & Assertion & Empathy & Cooperation & \multicolumn{1}{c}{ Self-control } \\
\hline School Retention & -0.066 & $-.263^{*}$ & -.016 & -.128 \\
Average Grades & $.216^{*}$ & .119 & .155 & $.373^{* *}$ \\
School Absence & -.11 & $-.248^{*}$ & -.094 & -.051 \\
\hline$M(S D)$ & $11.5(2.7)$ & $15.1(3.3)$ & $13.6(2.4)$ & $12.1(3.2)$ \\
\hline
\end{tabular}

${ }^{*} \mathrm{p}<.05,{ }^{* *} p<.01$

their academic results, levels of absence or school retention.

Correlations were calculated amongst the main variables studied in order to explore possible relationships amongst them, looking particularly at variables associated with academic performance. Table 5 and 6 show the coefficient scores amongst social skills and academic results, school absence and retention.

For all adolescents there was a significant positive correlation between academic results and their reported levels of Assertion and Selfcontrol. It was also shown that school retention was negatively associated with levels of Empathy. Interestingly, reported levels of Empathy was also positively related to the number of years living in the country, with a correlation coefficient of $.302(p<.05)$, negatively associated with students' total level of school absence without parents' permission $(-.275, \mathrm{p}=$
$.01)$, and positively associated with mothers' Educational Level $(.249, \mathrm{p}<.05)$.

Still in relation to the sub-scale Empathy, some significant gender differences were observed, with girls obtaining higher average scores. This pattern of significant gender differences was also observed for Cooperation, again with girls showing an advantage. Results are shown in table 7.

Other group differences were explored reflecting the main focus of the study, namely based on immigration status. Groups of firstand second-generation adolescents varied significantly in relation to the fathers' educational level and fathers' and mothers' work situation. T-test results are presented in table 8 and show that the parents from second generation immigrants had, on average, lower levels of qualifications and employment rates.

Table 7

t-tests for gender differences on two dimensions of social skills: empathy and cooperation

\begin{tabular}{l|lllll}
\hline & & Mean (SD) & $t$ & $d f$ & Sig. level \\
\hline Empathy & Girls & $15.8(3.1)$ & 2.3 & 87 & $\mathrm{p}<.05$ \\
& Boys & $14.3(3.4)$ & & & \\
& & & & & \\
Cooperation & Girls & $14.1(2.1)$ & 2.0 & & $\mathrm{p}<.05$ \\
& Boys & $13.1(2.7)$ & & & \\
\hline
\end{tabular}




\section{Discussion}

The present study showed some interesting results regarding first- and second-generation group differences in terms of perceived social skills, with the second-generation adolescents reporting lower levels of Self-control and Cooperation.

It is interesting to observe some apparently advantages for the way first-generation immigrant adolescents perceived their social skills. Thus, in accordance to other studies, results indicate some advantages for this first-generation youth in terms of their socio-cultural adaptation, school adjustment and behaviour problems (Sam et al., 2008).

Intervention programmes in schools should, then, be more sensitive to the adaptation process of second-generation students. Therefore, despite the fact that they were born and raised in the host country, as Strohmeir and Schmitt-Rodermund (2008) argued, they may show different patterns of social-cultural adaptation from first-generation immigrants.

A second interesting result relates to the positive associations between social skills, such as Assertion and Self-control, and aca- demic results. These skills have been found to be positively associated with academic performance by previous studies on other non-immigrant populations (Mansfield, Pinto, Parente, \& Wortman, 2009; Rice, 2006).

Our results seem to support previous evidence highlighting the importance of self-control in the academic outcomes of adolescents. For instance, Duckworth, Quinn and Goldman (2011) found a strong link between self-control and academic performance. Their study with children in early adolescence established that self-control had an effect on the students' grades over time, through the mediation that it has on their behaviour. Furthermore, self-control predicted longitudinal changes in grades better than did IQ (Duckworth et al., 2011). As these authors suggest, the importance of selfcontrol on academic results comes from the fact that this is a competence crucial to both learning related behaviour in the classroom and completing homework.

Likewise, the significant positive correlations found between assertiveness and academic results for the immigrant adolescents in the present investigation suggest that the

Table 8

Significant differences in terms of $1^{\text {st }}$ and $2^{\text {nd }}$-generation immigrants in relation to parents' educational level and labour situation

\begin{tabular}{l|llllc}
\hline & & Mean (SD) & t-test & $d f$ & level of sig \\
\hline Fathers' educational level & $1^{\text {st }}$ Generation & $2.35(.71)$ & 2.2 & 54 & $<.05$ \\
& $2^{\text {nd }}$ Generation & $2.0(.59)$ & & & \\
& & & & & \\
Fathers' working situation & $1^{\text {st }}$ Generation & $.96(.19)$ & 2.3 & 80 & $<.05$ \\
& $2^{\text {nd }}$ Generation & $.81(.40)$ & & & \\
Mother's working situation & $1^{\text {st }}$ Generation & $.81(.39)$ & 2.1 & 92 & $<.05$ \\
& $2^{\text {nd }}$ Generation & $.60(.50)$ & & & \\
\hline
\end{tabular}


former is a significant variable for adolescents' social development. Levels of assertiveness might be particularly important for immigrant adolescents to help them cope with cultural-transitions and challenges faced in the new social and cultural environment (Korem et al., 2011). Korem and collaborators (2011, pp.2) explain that assertiveness might be crucial to help adolescents to effectively "negotiate their needs openly and directly through this challenging period". Immigrant adolescents who develop high levels of assertiveness and self-control are probably less likely to adopt impulsive behaviours, tend to claim their rights in an appropriate manner (Wong et al., 2004) and find it easier to adjust to the challenges faced in school environments.

It seems important to better understand those pro-social skills that seem to have the greatest impact in the process of adaptation to the challenges that may be more directly linked to school performance. This knowledge will help to design and to implement intervention programmes specifically targeted to this population. Enhancing social skills amongst the immigrant school population may help them to be better prepared to face some of the stress factors of settling in a new school environment in the new country. There has been evidence from intervention programmes that social skills can be promoted even with shortterm training approaches (e.g., Evans \& Stefanam, 2009).

Promoting social skills such as empathy and cooperation in their non-immigrant peers may also contribute to an environment that supports multiculturalism and indirectly pro- motes better academic results for immigrant students (Chang \& Le, 2010).

On the one hand, the process of acculturation leads to changes in the individual's sense of identity. On the other hand, adolescence brings changes in the individual and the relevance of peers in that process. Promoting social skills, may therefore support psychological and academic adjustment.

So far, we have focused the present discussion on those social skills that have shown significant positive associations with the sample's academic results. However, it also seems relevant to, even if briefly, address here the importance of empathy as this variable has shown in our study some association with the number of years living in the country and with school absence. Although in this investigation no direct links were found between this important variable and school results, other studies have clearly underlined this link. For instance, empathy has been characterized as a key constituent to emotional and social behaviour and to contribute significantly to an adolescent's effectiveness in social and learning situations (Feshbach \& Feshbach, 2009). Also, empathy has been shown to be an important factor in the development of positive social behaviours and studies, such as the present one, have found girls to report higher levels of empathy than boys (e.g., Garaigordobil, 2009). The same gender pattern was found in the present study for Cooperation.

Finally, several limitations of the present study need to be highlighted. Being only exploratory in its nature, the present results ought to be analysed with some care as future 
research is needed to verify in greater detail the associations observed between some of the variables studied, and also compare these with data from non-immigrant adolescents. The methodology used in the present study is mainly correlational which makes it impossible to defer any causal relationships amongst the variables analysed here. Outcomes from studies on immigrant groups are always part of a complex set of variables including specific cultural, individual and developmental factors that interact in a complex way. Furthermore, the instruments used in this research involve self-report measures, which although fundamental in studying variables such as social skills, also carry with it the bias of social desirability (Garaigordobil, 2009).

\section{Conclusion}

As children move into adolescence new challenges emerge, such as, changes in the individual's sense of identity, the role of significant adults and the relevance of peers. Adolescents who fail to develop effective social skills may face difficulties in responding to these new challenges, resulting in poor outcomes, including lower levels of school achievement.

Successful learning in school requires students to interact and cooperate with peers and adults at different levels, it also involves the ability to regulate their behavior, to direct and control attention, delay rewards, express needs and many other abilities that depend on the development of a range of social skills. Cross-cultural transitions place even greater demands on social competence and the ability to adjust. Adolescent immigrants are in the process of developing their own identity while faced with the constant need to successfully shift between the norms and values of their host culture and their own family context. Social skills are therefore crucial in supporting immigrant adolescents to adapt to different social environments and to the school context.

Many schools are presently becoming more culturally diverse and this raises an important opportunity for researchers to develop relevant studies about the immigrant school population and offer directions for intervention. Schools that specifically promote social skills may, at least in part, be supporting more vulnerable students in a developmental period that places extra demands on their ability to form significant relationships with their peer groups. As discussed throughout the present study, the development of poor social skills places young people at higher risk of poor adaptation to the demands placed on them by the school environment. Evidence from the present data supports the link between social skills, such as assertion and self-control, and immigrant students' academic results. It also highlights the importance of taking into consideration differences amongst immigrant groups such as first- and second-generation, reminding us of the complex and intricate play that different variables exert on learning and behavior. 


\section{References}

ACIME (2005). Estatística da Emigração. Alto Comissariado para a Imigração e Minorias Étnicas, Presidência do Conselho de Ministros. Retrieved from http://www.scribd. com/doc/9556793/Estatisticas-da-imigracao-em-Portugal

Allen, J., Moore, C. Kupermic, G. \& Bell, K. (1998) Attachment and adolescent psychosocial functioning. Child Development, 69, 5, 1406-1419.

American Psychological Association. (2002). Developing adolescents. A reference for professionals. Washington, DC: American Psychological Association. Retrieved from http://www.apa.org/pi/pii/develop.pdf

Berry, J.W. (1980). Acculturation as varieties of adaptation. In A. Padilla (Ed.). Acculturation. Theory, Models and Findings (pp. 9-25). Boulder, CO: Westview Press.

Brindis, C., Wolfe, A., Mccarter, V., Ball, S., \& Starbuck-Morales, S. (1995). The associations between immigrant status and risk-behavior patterns in Latino adolescents. Journal of Adolescent Health, 17, 99-105.

Brown, B. \& Larson, J. (2009). Peer relationships in adolescence. In R. Larven \& L. Steiberg (Ed.), Handbook of adolescent psychology (pp. 74-103). New Jersey: John Wiley \& Sons.

Chang, J. \& Le, T.N. (2010) Multiculturalism as a dimension of school climate: the impact on the academic achievement of Asian American and Hispanic youth. Cultural Diversity Minor Psychology, 16 (4), 485-492.

Durlak, J., Weissberg, R., Dymnicki, A., Taylor, R., \& Schellinger, K. (2011). The impact of enhancing students' social and emotional learning: a meta-analysis of school-based universal interventions. Child Development, 82(1), 405-432.

Duckworth, A., Quinn, P., \& Goldman, S. (2011). What no child left behind leaves behind: a comparison of the predictive validity of self-control and IQ for standardized test scores and report card grades. Journal of Educational Psychology. Advanced online publication: doi: 10.1037/a0026280.

Elmore, R. (2009). Schooling adolescents. In R. Larven \& L. Steiberg (Ed.). Handbook of adolescent psychology (pp. 193-227). New Jersey: John Wiley \& Sons.

Evans, A., \& Stefanan, C. (2009). Behavioral academic effects of skillstreaming the adolescent for at-risk middle school students. NERA Conference Proceedings 2009, paper 25.

Feshbach, N. \& Feshbach, S. (2009). Empathy and education. In Decety, J \& Ickes, W. The social neuroscience of empathy (pp. 85-98). Massachusetts: Institute of Technology.

Fry, R. (2007). Are Immigrant Youth Faring Better in U.S. Schools? International Migration Review, 41(3), 579-601.

Fuligni, A. J., \& Hardway, C. (2004). Preparing Diverse Adolescents for the Transition to Adulthood. The Future of Children, 14(2), 99120.

Garaigordobil, M. (2009) A comparative analysis of Empathy in childhood and adolescence: gender differences and associated socio-emotional variables. International Journal of Psychology and Psychological Therapy, 9(2), 217-235.

Gresham, F., \& Elliot, S. (1990). Social Skills Rating System. Circle Pines, MN: AGS.

Huynh, V., \& Fulligni, A. (2010). Discrimination hurts: the academic, psychological, and physical well-being of adolescents. Journal of Research on adolescence, 20(4), 916-941.

Johnson, M.A. (2007). The social ecology of acculturation: Implications for child welfare services to children of immigrants. Children and Youth Services Review, 29, 1426-38.

Korem, A., Horenczyk, G., \& Tatar, M. (2011). Inter-group and intra-group assertiveness: adolescents' social skill following cultural transition. Journal of Adolescence, doi:10.1016/j.adolescence.2011.12.002. 
Lleras, C. (2008). Do skills and behaviours in high school matter? The contribution of noncognitive factors in explaining differences in educational attainment and earnings. Social Science Research, 37(3), 888-902.

Maleck, C. \& Elliot, S. (2002). Children's behaviours as predictors of academic achievement: a longitudinal analysis. School psychology Quarterly, 17 (1), 1-23.

Mansfield, P., Pinto, B., Parente, D., \& Wortman, W. (2009). College students and academic performance: a case of taking control. NASPA Journal, 46, 502-518.

Ortega-Ruiz, R., \& Rodrigues-Hidalgo, A. (2008). Peer victimization in multicultural schools in Spain and England. European Journal of Developmental Psychology, 5 (2), 507-535.

Pavlopoulos, F., Obradavic, J., Dalla, M., Takis, N., Papathanassiou, A., \& Masten, A. (2008). Immigration as a risk factor for adolescent adaptation in Greek urban schools. European Journal of Developmental Psychology, 5(2), 235-261.

Queen's University (2010). First-generation immigrants to Canada struggling in education system. ScienceDaily. Retrieved from: http://www.sciencedaily.com

Rice, D. (2006). An examination of emotional intelligence: Its relation to academic achievement in army JROTC and the implications for education. PhD Dissertation. Capella University.

Sam, D., Vedder, P., Liebkind, K., Neto, F., \& Virta, E. (2008). Immigration, acculturation and the paradox of adaptation in Europe. European Journal of Developmental Psychology, 5(2) 138-158.

SEF (2011). Relatório de imigrações fronteiras e asilo 2010. Oeiras: SEF. Retrived from: www. sef.pt

Steedly, k., Schwartz, S., Levin, M., \& Luke, S. (2008). Social skills and academic achievement. Evidence for Education, 3(2). Retrieved from http://nichcy.org/wp-content/up- loads/docs/eesocialskills.pdf

Strohmeir, D., \& Schmitt-Rodermund, E. (2008). Immigrant youth in European countries: The manifold challenges of adaptation. European Journal of Developmental Psychology, 5(2) 129-137.

Wong, D., Lam, D., Yan, P., \& Hung, M. (2004). The impact of acculturative stress and social competence on the mental health of mainland Chinese immigrant youth in Hong Kong. British journal of Social Work, 34, 1009-1024. 